\title{
Cormation
}

Nordic Journal of Art and Research

ISSN: 1893-2479

$\underline{\text { www.artandresearch.info }}$

\section{Autoetnografisk undersøkelse av dansepedagogiske vendepunkt - bevisstgjøring av forforståelse i kvalitativ forskning.}

\author{
Trine Ørbæk ${ }^{1}$ \\ Norges idrettshøgskole, Oslo
}

\begin{abstract}
Sammendrag: Artikkelen omhandler en autoetnografisk undersøkelse av en pedagogisk praksis med å undervise i skapende dans. Denne studien er en del-studie av PhD-prosjektet « $\AA$ skape dans» $i$ kroppsøvingslærerutdanningen som er forankret ved Norges idrettshøgskole og Nasjonal forskerskole for lærerutdanning. Livsfortellinger brukes som metode, og vendepunkt benyttes som analytisk verktøy. Vendepunktsanalysen får fram at en autoetnografisk undersøkelse er relevant for å bevisstgjøre egen forforståelse av å kunne utvikle pedagogiske erfaringer fra eget forskningsfelt. I tillegg vises at vendepunktsanalyse kan bidra til en økt kunnskap om hvordan ens egen erfaring har endret seg, ved at den er fortalt på nye måter. Det konkluderes med at bruk av autoetnografi kan ha verdi som en refleksiv tilnærming til synliggjøring av egen forskerprosess.
\end{abstract}

Emneord: Autoetnografi, forforståelse, vendepunktsanalyse, livsfortellinger, dansepedagogikk

\section{Innledning}

Artikkelen er utarbeidet $\mathrm{i}$ forbindelse med PhD-prosjektet «A skape dans» $i$ kroppsøvingslaererutdanningen. I kvalitativ forskning må forskerens forforståelse om det studerte feltet synliggjøres (Fangen, 2010; Denzin, 1989), siden denne forforståelsen både vil influere forskerens forståelse av det undersøkte felt, samt forståelsen av hvordan datamaterialet blir utviklet. Før jeg begynte å arbeide med undersøkelsen om kroppsøvingslærerstudentenes erfaringer med skapende dans, valgte jeg å gjøre eksplisitt den forståelsen jeg hadde av min egen erfaring med å skape dans og å undervise i skapende dans.

I denne artikkelen presenterer jeg først hvordan autoetnografi kan benyttes som tilnærming for å synliggjøre forskerens forforståelse. Deretter beskrives livsfortellinger som metode, før den fenomenologisk-narrative analysemodellen blir presentert. Deretter presenteres en vendepunktsanalyse

\footnotetext{
${ }^{1}$ Norges idrettshøgskole, Postboks 4014 Ullevål Stadion, 0806 Oslo. E-post: trine.orbak@nih.no 
av to situasjoner fra min pedagogiske praksis, før jeg reflekterer over vendepunktsanalysen i en metanarrativ. Avslutningsvis reflekteres det over valg av autoetnografi som metode for synliggjøring av min forforståelse. Forskningsspørsmålet i artikkelen, er: Hvordan kan en autoetnografisk undersøkelse bidra til å bevisstgjøre hvilken forforståelse som kan ha vært implisitt i min undervisning i skapende dans?

\section{Autoetnografisk undersøkelse}

En autoetnografisk undersøkelse blir av etnografer benyttet for å synliggjøre forskerens forforståelse av det studerte feltet, som igjen vil danne grunnlaget for hvilke spørsmål forskeren søker svar på underveis i sitt arbeid. Jeg forsøker å undersøke den kultur jeg lever i, i den hensikt å opparbeide kunnskap om min erfaring med å undervise i skapende dans. For å nærme meg min egen forforståelse, posisjonerer jeg meg innenfor et fenomenologisk vitenskapsperspektiv som er inspirert av etnografiske studier innen antropologi og sosiologi. Katz \& Csordas (2003) mener at antropologer som forsker innenfor "erfaring" blir ansett som fenomenologer ved at de anerkjenner kroppen som et uttrykk for historisk erfaring. En slik kulturell fenomenologi er karakterisert som "an emphasis on embodiment as the common ground for recognition of the other's humanity and the immediacy of intersubjectivity" (s. 270). Katz \& Csordas anser dessuten at sosiologer er fenomenologer når de forsker innenfor livsverdenstrukturer der de vil "probe beneath the locally warranted definitions of a local culture to grasp the active foundations of its everyday reconstruction" (s. 284-285). Undersøkelsen dette kapittelet bygger på er inspirert av Katz \& Csordas forståelse av etnografiske studier.

\section{Livsfortellinger}

For å få tilgang til egen pedagogisk erfaring kan livsfortelling være en egnet metode. En livsfortelling er en fortelling som en person forteller om sitt liv eller deler av sitt liv. En slik fortelling benevnes som selvbiografisk og kan synliggjøre hvordan mennesker opplever sine liv (Denzin, 1989). Livsfortellingen blir i en moderne, vestlig sammenheng, definert som konstruert og etablert innenfor en spesifikk kulturell, historisk og sosial sammenheng. Menneskenes egne tolkninger settes i sentrum med all sin kompleksitet og sine motsetninger (Johansson, 2010). Fortellinger kan forstås som visuelle og skriftlige uttrykk for erfaringer (Johansen, 2010). Datamaterialet som ligger til grunn for denne studien inkluderer derfor både bilder og tegninger sammen med skriftlige tekster som samlet består av 4736 sider med refleksjonsnotater, forelesningsnotater, dagbøker, undervisningsplaner og akademiske oppgaver jeg har skrevet i perioden 26.8.1991 til 31.5.2011. For å analysere disse livsfortellingene benytter jeg vendepunkt som analytisk verktøy. Denzin (1989) mener at livsfortellinger konstrueres innenfor en spesifikk fortelling, i en spesifikk situasjon, med visse fortellerteknikker. Livsfortellinger bør, i følge Denzin (1989), analyseres gjennom å studere subjektets vendepunkter. En slik fenomenologisk tilnærming til vendepunktanalyse inspirerte meg.

\section{Vendepunktsanalyse}

Det første steget $\mathrm{i}$ analysen var å lete etter situasjoner fra mitt omfattende materiale som kunne indikere endringer i min lærerrolle i skapende dans. Jeg forsøkte å identifisere endringer, i tråd med slik Denzin (1989) definerer vendepunkt som de kriser eller avgjørende hendelser i et menneskes liv når livet tilspisser seg, som når individets karakter avsløres eller blottlegges. Disse vendepunktene deler inn livet i et "før" og "etter". Min hensikt var både å se hvordan jeg hadde omtalt undervisningen i skapende dans, og hvordan jeg hadde omtalt de endringene jeg hadde foretatt i min pedagogiske 
praksis. Gjennom en narrativ innholdsanalyse, narrativ formanalyse, narrativ personsentrert analyse (Johansson, 2010) og fenomenologisk analyse (Reeder, 2010), identifiserte jeg to situasjoner som jeg tolket som viktige pedagogiske vendepunkt. Disse ble tydelige både ved å se hvilke ord og hvilken form jeg hadde valgt for å uttrykke mine tanker om undervisningen i forkant, hvordan og hva jeg skrev underveis i undervisningen, samt hvordan og hvilke refleksjoner jeg skrev ned etter undervisningen. Jeg gjenkjente mindre vendepunkt i forkant av disse hovedvendepunktene, men valgte å gripe fatt i de situasjonene som jeg tolket som klimaks i materialet.

Det første vendepunktet er skrevet som et refleksjonsnotat over FoU-prosjektet Integrerte dansere - en hermeneutisk studie av ulikkroppede dansere $i$ den videregående skolen som var en oppgave $\mathrm{i}$ min praktisk-pedagogiske utdannelse ved NTNU, våren 2008:

\section{1. vendepunkt}

Da jeg våren 2007 takket ja til å være lærer for prosjektet som skulle inkludere funksjonsfriske og funksjonshemmede elever ved danselinjen ved Skien videregående skole var jeg veldig spent på hvordan, og om, jeg ville klare å gjennomføre et undervisningsopplegg som oppnådde læring hos elevene. Innenfor det å undervise funksjonshemmede elever hadde jeg tidligere kun erfaring fra å ha undervist en gutt på 6 år med Downs syndrom på ordinær kveldsundervisning $i$ dans ved Stiftelsen Studio Nille i Larvik. Dette prosjektet ble derfor en utfordring jeg både gruet og gledet meg til. Jeg visste at dette var første gang et slikt prosjekt ble gjennomført ved en videregående skole og at det måtte være høy takhøyde for å diskutere utfordringer og gode opplevelser. I forkant av prosjektet møtte jeg Per sine foreldre som ga meg mot og støtte til å sette i gang, og gjennom gode diskusjoner med en reflektert avdelingsleder og T-leder [tilpasnings-leder] ved Skien videregående skole opplevde jeg trygghet nok rundt meg til å kaste meg ut $i$ dette nye landskapet. Det ga også trygghet å ha 14 års undervisningserfaring $i$ dans og kjennskap til mange undervisningsmetoder og øvelser.

Til mitt første møte med denne gruppen hadde jeg forberedt meg på å gjennomføre kurset "Dans din dans". Min 10 års undervisningserfaring fra dette kurset har gitt meg mange innfallsvinkler og variasjoner over øvelser som jeg håpet kunne benyttes, og jeg hadde mange gode minner fra hva tidligere elever har oppnådd av læring gjennom kurset. Men, min første dag av FoU-prosjektet ble en skikkelig nedtur. I min logg fra bussturen hjem fra jobb den dagen står det blant annet: "jeg stresser gjennom mitt eget undervisningsopplegg og tar ikke imot impulser fra elevene om å endre kurs når noe ikke fungerer", "jeg tar for mye plass både i ord og bevegelse", "min tålmodighet er liten når jeg ser at elevene ikke oppnår det jeg håpet de enkelte øvelsene skulle gi", "jeg møter mine fordommer med å tro at Per ikke klarer noe og at de andre ikke vil jobbe med ham", "jeg bruker altfor mye tid på Per i forhold til de øvrige elevene". I tillegg opplevde jeg at prosjektet kanskje skulle hatt mer spesialpedagogisk tyngde enn det jeg hadde kompetanse på, og at dette hindret meg i å se prosjektet $i$ et kunstnerisk-pedagogisk lys. Dette var uheldig både for elevene og for meg. Jeg følte jeg hadde overvurdert min undervisningskompetanse og så at det kurset jeg prøvde å gjennomføre ikke var mulig å få til grunnet Per sine begrensninger, motivasjon og utrygghet med gruppen og mine begrensninger innen valg av øvelser, bruk av ord, fokus og interesse. Det jeg hadde forberedt meg på fungerte overhode ikke med denne gruppen og jeg klarte heller ikke å ta selvkritikk før på veien hjem. Skuffelsen over min egen arroganse og vilje til å gjennomføre "mitt stoff" ga meg en god latter da jeg innså hva jeg holdt på med. Gjennom å se hva jeg hadde gjort $i$ disse tre første timene forberedte jeg meg så til de siste tre timene av FoU-prosjektet. Hva kunne jeg forbedre? Hva måtte jeg fokusere på? Hvordan kunne jeg få elevene til å oppleve et godt læringsrom? Hvordan kunne jeg tilpasse intensjonen med kurset "Dans din dans" til denne elevgruppen?

I forkant av dette vendepunktet var mine tekster preget av at jeg hadde utarbeidet nøyaktige beskrivelser av hvilke øvelser som skulle til for å lære bort trinn og formasjoner til elevene, samt tydelige tegninger om hvordan scenografi, kostymer, rombruk og relasjoner skulle se ut til slutt. Jeg skrev ingenting underveis i timene, og da jeg reflekterte i etterkant omhandlet dette kun i hvilken grad 
jeg hadde klart å lære bort det planlagte innholdet til elevene. Deretter laget jeg en oversikt over trinn og formasjoner jeg skulle lære bort til elevene neste time. Undervisningen hadde som mål å lære elevene hvilke grunnelementer en dans skulle bestå av og hvordan bevegelsene kunne settes sammen til bevegelsesfraser som igjen kunne utvikles til danser. Denne kunnskapen var inspirert av Labans bevegelsesteorier fra 1930-tallet (Laban, 1988). Deler av denne bevegelsesteorien var også sentral i min utdanning som koreograf ved Statens balletthøgskole. Det er denne forståelsen om å skape dans som, i følge Jensen (2008), i stor grad er gjeldende i kroppsøvingsfaget i skolen i dag. Etter det første vendepunktet ble forberedelsestekstene annerledes og fylt med åpne spørsmål, variasjoner over øvelser og undrende spørsmål til elevenes opplevelse. Underveis i undervisningen noterte jeg situasjoner som fanget min oppmerksomhet, og i refleksjonstekstene etter timene søkte jeg svar på hva jeg hadde opplevd i undervisningen. På denne måten begynte jeg å stille spørsmål til hvilken kunnskap den skapte dansen inneholdt for de som skapte den og hvordan jeg som lærer kunne legge til rette for den skapende prosessen i dans.

Det andre vendepunktet er skrevet om i et refleksjonsnotat jeg har datert 31.5.2011. Det er basert på skriftlige tekster, tegninger og minner fra en innstuderingsperiode med en profesjonell danser. I dette refleksjonsnotatet inkluderte jeg også utdrag fra danseren Karoline sitt refleksjonsnotat (datert 20.5.2011) som hun hadde skrevet ut fra notater og minner fra samme innstuderingsperiode:

\section{2. vendepunkt}

Min reaksjon på å bli separert fra min mann var å lage en dans med utgangspunkt $i$ egen kropps ønsker og muligheter for bevegelser. Jeg merker at kroppen har sin egen vilje, intensjon og retning og velger å følge de impulser kroppen gir meg for bevegelse. Da dansen, fra kroppens ønsker er ferdig, utvikler jeg et stort behov for å dele den med noen, og den klareste måten å fortelle om denne livserfaringen, var å lære den bort. Jeg måtte få kontakt med en danser, og ringer Karoline. Da jeg kom til dansestudioet, hadde jeg tenkt å lære fra meg dansen jeg hadde laget, men kroppen min orket ikke. Den var tom og med høye muskelspenninger. Kroppen klarte ikke vise de bevegelsene jeg hadde arbeidet så mye med, og ordene mine kunne ikke beskrive dem. I et innfall bestemmer jeg meg for å dele min nye livssituasjon med henne, og hvordan jeg kroppslig hadde reagert. Tilfeldigvis er hun i samme livssituasjon som meg. Hun har muskelvondt. Som meg. Overalt. Vi deler våre erfaringer om samme fenomen. Et nytt innfall inntreffer: "Skal vi våge, Karoline?", spør jeg. Nå hadde vi muligheten til å utforske hvordan livserfaringer forankrer seg $i$ kroppene våre, siden de smertefulle kroppene våre hindrer oss $i$ å gjøre det hodet ønsker. "Skal vi tørre å kjenne dypt etter hvordan kroppene våre erfarer å være $i$ denne livssituasjonen?" La vår felles livserfaring være utgangspunkt for den kroppslige utforskingen?" Vi startet med å varme opp hver for oss. Sakte. Før vi forsiktig startet med å bevege oss samtidig i hver vår verden, utforsket våre kroppslige fornemmelser. Jeg utforsker min høyre skulder. Den har vært anspent i flere uker. Karoline beveger seg uten å bøye hodet. Hennes bihuler, ører, hals og nese er blokkert, betent. Karoline skriver i sitt refleksjonsnotat: "Jeg faller, vakler, svimler og finner frihet $i$ å tørre. Jeg er lukket, spent, dirrer av anspenthet. Kompakt, sammentrykt, forkrøplet". Vi deler ord og bevegelser med hverandre. Karoline velger de ord hun kjenner står henne nærmest, eller som er sterkest $i$ forhold til hvordan hun føler seg $i$ dag. Ordene står ikke separat, de henger sammen, og hun lager små bevegelsesfraser over 4 temaer: 1) falle, vakle inn i, sirkel å gå ut av, 2) ømme stive muskler, på tå hev, anspenthet, frustrasjon, 3) distansere, steinansikt, rakrygget, bøye nakken, fosterstilling. Apati, 4) legge lokk på den boblende vulkanen. Jeg veksler mellom å bevege den høyre skulderen min i relasjon til ordene "holde tilbake" og "fri", og opplever en avspenning av den anspente skulderen når den "riktige" bevegelsen finner sitt uttrykk. "Hva er dette? Hvorfor gjør vi dette nå? Hvorfor dette sterke behovet for å dele dette? Vi setter våre "riktige" bevegelser sammen i en meningsfull rekkefølge. Karoline skriver: "Det kjennes godt å være to, det kjennes viktig å gjøre dette, bevege oss sammen." 
Tekstene etter dette vendepunktet skilte seg fra de andre ved at det ikke inneholdt forberedelsesnotater, men underveis i innstuderingssituasjonen skrev jeg ned enkeltord som for eksempel låst, bevegelig, sårbar, ubalanse, intuisjon og sveve. Sammen med danseren ble disse ordene fortløpende satt sammen i betydningsfulle relasjoner til hverandre. Etter undervisningstimen viste refleksjonene seg gjennom tegninger, og metaforer, for følelser og bevegelser. Tegningene og bokstavene vekslet mellom å ta stor og liten plass på arket. Innimellom sidene var det blanke ark.

\section{Lærerroller}

Det andre steget $\mathrm{i}$ analysen av begge disse situasjonene er inspirert av narrativ analyse (Johansson, 2010), fenomenologisk analyse (Reeder, 2010), samt en arts-based analyse som ble introdusert gjennom et praktisk, kvalitativt analysekurs med Liora Bresler i Trondheim 9. og 10. mai 2011. Analyseprosessen begynte med at jeg leste de utvalgte refleksjonsnotatene to ganger hver dag, morgen og kveld. Fokuset for lesningen var å undersøke hvem som forteller hva til hvem, når, hvor, i hvilken situasjon og med hvilken hensikt (Johansson, 2010). I løpet av denne leseprosessen skrev jeg ned i detalj hva disse to tekstene fortalte meg, hvilken relasjon jeg så mellom detaljene og hvordan jeg hadde brukt språket til å uttrykke erfaringen. Etter hvert som jeg leste, opplevde jeg at tekstene kommuniserte tilbake til meg. Armstrong (sitert i Bresler, 2011) hevder at en slik dialog kan oppstå når vi retter oppmerksomheten vår mot noe som interesserer oss. Bresler mener at en slik kommunikasjon er viktig i kvalitativ forskning. Videre analyserte jeg refleksjonsnotatene i relasjon til hva de handlet om for meg. Etter tretti dager oppdaget jeg ikke lengre noen ord eller setninger, eller relasjoner mellom dem, som fortalte meg noe nytt. Min tolkningsprosess hadde nådd sitt metningspunkt (Fangen, 2010). Inspirert av Heidegger sitt vitenskapsfilosofiske perspektiv om at intuisjon og kroppslige reaksjoner er kilde til kunnskap, inkluderte jeg også min kroppslige følsomhet som analytisk perspektiv i denne analysen (Katz og Csordas, 2003). Jeg opplevde at kroppen ble urolig, stresset og redd da jeg leste om situasjonene på ny. Jeg svettet, holdt pusten, fikk vondt i magen og opplevde skjelvinger. Dette kroppslige minnet henviser til måter som den fenomenologiske kroppen i seg selv husker sin egen aktivitet (Burton, 2011). Kroppen husket den situasjonen jeg leste om.

\section{Fra mesterlarer til veileder}

Det første vendepunktet kan tolkes i relasjon til mesterlærertradisjonen (Molander, 1996). Jeg inntok en rolle som mesterlærer, og anså dermed elevene som mine lærlinger. Undervisning i dans er sterkt forankret i mesterlæretradisjonen (Østern, 2008). Den bygger på imitasjon, der målet er at danserne skal bli gode "verktøy" for koreografers arbeid. I følge Østern (2008) har det vært lite rom for at "lærlingen" skal lære å skape egen dans. Innholdet og metodene jeg benyttet, var modeller for hvordan dans kunne lages, basert på min erfaring som koreograf og utvikler av kurset jeg hadde valgt å skulle gjennomføre. Ved nærmere analyse fikk jeg fram at det ligger et paradoks i situasjonen i og med at kurset skulle motivere til utforskning og samarbeid, mens dette perspektivet ikke var forankret i min egen pedagogiske praksis. Ved å forstå det å skape dans som en «fastlagt» kunnskap jeg skulle «overføre» til elevene var mitt kunnskapssyn forankret i et positivistisk kunnskapssyn. Gjennom en formidlingspedagogisk tilnærming hadde jeg inntatt et behavioristisk læringssyn der jeg med utvalgte øvelser forventet at elevene skulle lære å skape dans på en bestemt måte (Imsen, 2003).

Analysen av tekstene tydeliggjorde at jeg opplevde skuffelse over det jeg anså som min egen prestasjon $\mathrm{i}$ undervisningsrommet og at denne følelsen kom tilbake ved lesning av materialet. 
Prosjektet var et prestisjeprosjekt både for meg, min egen arbeidsplass, i min utdannelse og blant mine kolleger ved danselinjen. Jeg hadde lagt ned mye arbeid i å forberede undervisningen. Ved å oppleve at jeg rettet fokus mest mot egen prestasjon, og ikke hva elevene skulle oppleve i møte med meg, gjorde jeg nye oppdagelser. Ved at min undervisningskompetanse kan ses som "å stå på stedet hvil", ble konsekvensen at jeg valgte å tenke ut fra at undervisningen dreide seg om å "overføre" min kunnskap om å skape dans, til elevene. Da jeg uventet møtte motstand fra elevene hadde jeg ikke pedagogisk kompetanse til å gjøre noe annet enn det jeg hadde i mitt daværende repertoar. Jeg mistet, i mine egne øyne, status som pedagog da jeg oppdaget at mine innlærte rammer for hva undervisning $i$ skapende dans var, ikke inneholdt kunnskap om denne problemstillingen. Jeg hadde møtt et problem i egen undervisning som medførte at mitt forsvar ble aktivert. Dette sammenfaller med hva Dreyfus og Dreyfus (sitert i Henriksen og Vetlesen, 2010) beskriver som nybegynnerfasen i å utvikle kompetanse i problemløsning. De mener at nybegynnere lar seg styre av sort/hvit - løsninger på sine problem, og at jo flere regler som læres, jo vanskeligere blir det å finne løsninger på unike problemer i unike situasjoner. Jeg hadde opparbeidet meg mange regler for hvordan undervisningen skulle være, og hva jeg mente elevene skulle lære av dette, men jeg visste ikke at undervisning også handler om å være god til å arbeide med unike problemer i unike situasjoner (van Manen, 1991). Det jeg imidlertid hadde mulighet til, var å reflektere over egne handlinger, og vilje til å utforske min pedagogiske praksis.

Da jeg begynte å reflektere over situasjonen fra undervisningsrommet, ble det tydeligere for meg hva, og hvordan, jeg hadde tenkt omkring det som hadde hendt. Ved å våge å oppleve noe som var krevende og vondt, erfarte jeg å finne en ny vei. Ved å møte min egen prestasjonsangst, kunne jeg snu dette slik at jeg fikk en ny erkjennelse av hvilken pedagog jeg framstod som. Den nye pedagogrollen jeg startet å utvikle dagen etterpå, er inspirert av Vygotsky og Bruner (Østern, 2008). Jeg ønsket å komme i dialog med elevene, og presentere øvelser som de mestret og kunne strekke seg etter. Jeg arbeidet dermed innenfor det Vygotsky definerer som «den proksimale utviklingssonen» (Imsen, 2003:159). Med det mener han avstanden mellom det eleven tror hun/han mestrer alene, og det hun/han mestrer med hjelp fra en pedagog eller medelev. Dersom elevene får oppgaver de føler de mestrer blir de interessert og klarer oppgaven. Jeg er også inspirert av Bruner og hans begrep "scaffolding" (Østern, 2008). I stedet for å skulle gi elevene mitt eget støtteverk for å skape dans begynte jeg å bli en støtte for deres utforskning mot å utvikle sin egen metode for å skape sin dans. Denne pedagogrollen passer inn i det bildet som framtrer i danseforskningen til Lavender (2006), Purcell Cone (2009), Haines (2006) og Davenport (2006a, 2006b). Deres forskning understreker betydningen av at læreren bør innta en mentorrolle i den skapende prosessen. Jeg opplevde også at jeg bokstavelig talt endret min pedagogiske praksis over natten. Gjennom å la elevene utvikle kunnskap om å skape dans gjennom et samspill med meg og de andre medelevene oppdaget jeg at det å skape dans også kan forstås ut i fra et sosialkonstruktivistisk kunnskapssyn (Imsen, 2003). På denne måten ser jeg at min pedagogrolle endret fokus fra å være en koreograf der mine elever blir objekter for det jeg vil at de skal lære og gjøre, til å bli en veileder som ønsker at elevene selv skal lære seg å skape sin egen dans.

\section{Fenomenologisk tilnærming til å undervise i dansekomposisjon}

I det andre vendepunktet kan det jeg beskriver igjen ses i lys av at jeg har inntatt en mesterlærerrolle, noe som innenfor dansekunstmiljøet ofte blir forventet av koreografer. Min pedagogiske rolle som koreograf har i stor grad vært preget av en formidlingspedagogikk som kjennetegnes ved at koreografen viser og forklarer trinn til danserne som deretter tilpasser disse bevegelsene til sin egen kropp. Diskusjonene har omhandlet i hvor stor grad danserne har mestret de bevegelsene jeg har laget, 
ut fra et klart forhåndsbilde jeg har skapt meg av den ferdige dansen. I tillegg har jeg tidvis utforsket deler av koreografien sammen med danserne, selv om min stemme alltid har vært avgjørende for hvordan koreografien skal presenteres til slutt. Det er jeg som har hatt det kunstneriske ansvaret. I vendepunktet jeg her belyser, opplever jeg at jeg "mister status" som koreograf i møte med danseren. Denne gangen blir jeg ikke skuffet, men mer nysgjerrig på hva som skjer. I stedet for å møte situasjonen med angst, opplever jeg undring. Jeg stiller spørsmålet: Hva gjør jeg nå? Kroppen og tanken er min mulighet for hva jeg kan mestre. Her utfordres rollen jeg har laget av meg selv som koreograf. I denne rollen var det viktig med en "sterk" kropp, klare meninger om hvordan dansen skulle uttrykkes, og hvordan danserne skal tilegne seg denne kunnskapen. I dag er dette bildet dekonstruert og endret, slik jeg selv ser det. Min rolle som koreograf er i endring grunnet en smertefull kropp som opplever en vanskelig separasjon. Det er nettopp en påtrengende smerte som jeg anser som grunnen til dette vendepunktet. Gjennom å møte på et problem jeg ikke kan løse som tidligere, opplever jeg at jeg lar kroppen min, og intuisjonen min, styre mine valg i undervisningsøyeblikket. Dette blir starten på å arbeide med en pedagogrolle med en fenomenologisk tilnærming til undervisning i skapende dans. Istedenfor å fokusere på dansen som et produkt, rettes blikket mot hvilke behov og muligheter jeg hadde for å bevege meg akkurat i øyeblikket. Å bevege meg ut fra dette utgangspunktet, opplevdes som en muskulær frigjøringsprosess så vel som en mental frigjøring. Da kroppen fant sitt bevegelsesuttrykk, "løsnet" den stive muskulaturen. I denne terapeutiske situasjonen, opplevde jeg at kroppen kom i dialog med tankene. Jeg tolket kroppen som en kilde til kunnskap som kunne fortelle meg noe om hvem jeg var, akkurat i øyeblikket. Når denne prosessen ble delt med danseren oppstod en intersubjektivitet som ga oss empati for hverandre. Denne situasjonen åpnet derfor opp for mitt møte med et somatisk læringsperspektiv som retter fokus mot kroppen som kunnskapskilde, en emansipatorisk pedagogikk som vektlegger undervisningens frigjørende potensial, og et subjektivt kunnskapssyn på å skape dans der uttrykket er en refleksjon over hvordan den enkelte opplever seg selv i relasjon til omverdenen. Disse perspektivene på å skape dans er fokus for flere forskere innen dansepedagogikk i Norden i dag (Anttila, 2007; Hyvönen, 2007; Hämäläinen, 2007; Kaupilla, 2007; Lilja, 2006; Østern, 2009).

En slik endring i min pedagogiske praksis, ble mulig ved å reflektere i handlingen, og ved å snakke om mine opplevelser. Empatien jeg erfarte endret min pedagogrolle fra å være mester til å være en deltaker i en inkluderende, skapende prosess, der vi begge var likeverdige subjekter som søkte uttrykk for sin eksistensielle angst.

\section{Utvikling av læreridentitet}

I det tredje steget av analysen koblet jeg de to vendepunktene sammen i en metanarrativ der det siste vendepunktet ble koblet kronologisk sammen med det første. Temporaliteten blir sett på som et nødvendig kriterium for hva som kan kalles en historie (Johansson, 2010). Denne historien blir en metafortelling, en fortelling om min fortelling, der jeg relaterer vendepunktene til diskurser om undervisning i skapende dans. Ved å benytte et perspektiv der både innhold og form omhandles, samt opplevelsen av teksten, ble målet for denne fenomenologisk-narrative analysemodellen å få fram hvilke perspektiver deler av min livshistorie som pedagog i skapende dans kunne forstås ut i fra.

De to vendepunktene tolker jeg som avgjørende øyeblikk for min pedagogiske praksis. Gjennom disse analysene har jeg fått fram at det å undervise i skapende dans kan ses både ut fra et positivistisk, et sosialkonstruktivistisk og et subjektivt syn på kunnskap. Jeg har også gjort eksplisitt at min pedagogrolle har vekslet mellom å være et uttrykk for mesterlærer, veileder og fenomenolog. 
Det som binder vendepunktene sammen, er hvordan jeg utvikler en undervisningskompetanse gjennom å møte og reflektere over problemer i min pedagogiske praksis. Refleksjonsprosessen bidrar til å utvikle min forståelse for pedagogrollen i undervisning i skapende dans. Gjennom å utvikle en pedagogisk praksis ved å reflektere over egen erfaring med å skape dans og problemer fra praksis konstruerer jeg samtidig en læreridentitet i skapende dans basert på de mulighetene og begrensningene jeg har som menneske. På denne måten kan vendepunktene ses som avgjørende situasjoner for min fortelling om meg selv som lærer. Denne utviklingsprosessen kan ses i sammenheng med de fem stadiene for utvikling av ferdigheter og problemløsningskompetanse som Vetlesen og Vetlesen (sitert $\mathrm{i}$ Henriksen og Vetlesen, 2010) skisserer: nybegynner, avansert nybegynner, kompetent utøver, profesjonell utøver og ekspert. Fra å være en nybegynner som så alt som svart/hvitt, beveget jeg meg videre til å bli en avansert nybegynner. Denne utviklingen ble tydelig ved at jeg begynte å forstå at det var min erfaring med ulike situasjoner som utviklet et større repertoar som lærer, og at jeg ikke kun var «fanget i» mine tillærte og objektive regler om hva undervisning i skapende dans var. I tillegg hadde jeg innsett at situasjonen jeg befant meg i, i det første vendepunktet, var sammensatt av en rekke ulike forhold, og at det var disse forholdene til sammen som avgjorde hvilke valg jeg tok videre. Da jeg laget nye mål og metoder for undervisningen "over natta”, endret jeg meg til å bli en pedagog som kontinuerlig reflekterte over egen praksis. Da jeg i det andre vendepunktet skulle lære danseren koreografien anså jeg meg selv som en profesjonell utøver som koreograf. Jeg var sterkt engasjert i det jeg arbeidet med, og jeg hadde lang erfaring fra ulike situasjoner i min koreografiske praksis som gjorde at jeg kunne løse ulike situasjoner intuitivt. Å møte et problem i denne utviklingsfasen, skapte nysgjerrighet og undring. Jeg inntok en analyserende holdning til situasjonen jeg befant meg i, og overveide ulike muligheter for problemløsninger. Jeg var det Vetlesen og Vetlesen betegner som en ekspert.

Samlet har min teoretiske kunnskap om å skape dans, min praktiske kunnskap om å skape dans og min kunnskap om problemløsning bidratt til å skape min læreridentitet i skapende dans. En slik læreridentitetsforståelse blir av lærerforskere beskrevet som et relasjonelt fenomen som blir formet og endret innenfor et mangfold av kontekstuelle og personlige elementer. Identitet blir forstått som ustabile, fleksible konstruksjoner som er avhengige av kontekstuelle og personlige endringer (Day, Kington, Stobart og Sammons, 2006). Min identitet som lærer i skapende dans er derfor i en stadig utvikling, og influeres av hvilke elever jeg har, hvilken kontekst jeg underviser i, min evne til å møte nye problemer samt min oppfattelse av meg selv som lærer. Inspirert av Foucault (1999) kan jeg si at denne livshistorien forteller hvordan jeg før vendepunktene hadde skapt meg noen diskurser knyttet til hva undervisning i skapende dans var, og at disse diskursene styrte min pedagogiske praksis. Da jeg oppdaget at diskursene kunne betraktes som pågående sannheter (Annfelt, 2000), innså jeg at jeg kunne utfordre min forestilling om hva undervisning i skapende dans kunne være. Gjennom å innta en refleksiv holdning til egen undervisning, endres og utvikles min pedagogiske praksis.

\section{Refleksjon over prosessen}

Det jeg ble oppmerksom på ved å benytte en fenomenologisk-narrativ tilnærming til vendepunktsanalysen, var at analyseprosessen tok meg med på en historisk reise i egen livsfortelling. Minner kom tilbake. Jeg luktet, følte og tenkte som den gang jeg skrev teksten. Jeg husket ting jeg unnlot å skrive grunnet skam og flauhet. I den perioden jeg skrev det første vendepunktet hadde jeg en kronisk syk sønn som krevde at jeg var mye våken på natten. I tillegg levde jeg sammen med en langtidssykemeldt mann som ikke kunne hjelpe meg med arbeidsoppgavene hjemme. Dette var temaer jeg opplevde som tabu i et samfunn som jeg i sterk grad opplevde som fokusert på familieidyll, 
prestasjoner og god helse. I tillegg hadde jeg et stort behov for å beholde jobben av økonomiske årsaker, siden jeg var den eneste i familien med inntekt i denne perioden. I det andre vendepunktet unngikk jeg å skrive om hvor klaustrofobisk jeg opplevde rommet, og meg selv. Å innrømme slike angstfulle erfaringer passet ikke inn den fortellingen jeg ville skape om meg selv. På denne måten ble begge vendepunktene skrevet innenfor det Roos (sitert i Johansson, 2010) betegner som "lykkefortellinger", et begrep jeg ser at passer i min situasjon

Jeg ble også oppmerksom på hvor godt kroppen husket vendepunktsituasjonene. Begrepet "kroppens minne" bygger på Bergson sitt begrep "habit memory", der kroppen ses som en "ever advancing boundary between the future and the past, as at a pointed end, which our past is continually driving forward into our future ... [M] body ... is ... when [placed] in the flux of time, always situated at the very point where my past expires in a deed." (sitert i Burton, 2011:27). "Habit memory" presenterer ikke vår fortid til oss, den uttrykker den. Kroppens minner innebærer derfor at kroppen tar med sin egen fortid og forholder seg til nåtiden gjennom en nær og osmotisk relasjon. Kroppens minner gjenkjenner jeg som det utgangspunktet jeg oftest har benyttet for egne skapende prosesser i dans. Jeg deler derfor Lilja (2006) sin erfaring med, og forståelse for, at dans kan være uttrykk for kroppens minner. Gjennom å lese egne tekster ble jeg klar over hvordan kroppslige minner også kan ha betydning for tolkningen av andres erfaringer. Ved å benytte kroppens minne som verktøy gjennom forskerprosessen kan jeg gjenkjenne situasjoner og følelser jeg selv har erfart som pedagog og koreograf, og dermed komme nærmere en forståelse av erfaringen som studentene forteller om. På denne måten kan også kroppen være et utgangspunkt for min kunnskap om andres erfaringer. Det forstår jeg som det Merleau-Ponty (2012) benevner som forskerens kroppslige intersubjektivitet.

$\AA$ ha en distanse til det datamaterialet jeg selv hadde skrevet, var en utfordring da de to situasjonene fremkalte minner fra to krevende perioder i mitt liv. Å analysere konteksten min tekst var skapt innenfor ville ha vært for sårbart samt veldig omfattende innenfor rammen av denne studien. For å klare å fokusere på vendepunktene, og ikke hva disse vendepunktene fremkalte av minner, valgte jeg å la kolleger, veiledere og venner lese de to utvalgte refleksjonsnotatene og diskuterte hva de mente tekstene handlet om. I tillegg leste jeg tekstene over så lang tid, og med så høy frekvens at jeg opplevde at jeg fikk en større distanse både til teksten, og gradvis også til minnene jeg hadde om situasjonene.

Det autoetnografiske arbeidet har også vært starten på å skape en forskerrolle som jeg identifiserer som en "a/r/tographer" (Irwin \& de Cosson, 2004). Denne rollen anerkjenner forskerens erfaring som artist, researcher og teacher som "kunnskapende" praksiser som påvirker og utfyller hverandre i den vitenskapelige "kunnskapingen". I tillegg innebærer begrepet at forskning innenfor kunst (art) formidles gjennom tekst (graphy). I PhD-studien ønsker jeg å benytte min erfaring som pedagog, koreograf og forskerstudent til å utvikle kunnskap om kroppsøvingslærerstudentenes erfaringer med å skape dans og å undervise i skapende dans. Min forståelse av studentenes erfaringer gjennom deres fortellinger, krever derfor en sterk refleksiv tilnærming til "a/r/tographer" rollen, som bør pågå parallelt med min studie av studentenes erfaringer. Refleksivitet i kvalitativ forskning handler om å forsøke å få svar på spørsmålene: Hva vet jeg? Hvordan vet jeg det? (Hertz, 1997). Det er derfor vesentlig at jeg hele veien forsøker å stille spørsmål til hvordan datamaterialet og funnene har blitt skapt, hva jeg forstår ut i fra datamaterialet, og hvorfor jeg forstår det på den måten. Dette kan møte forskningens krav til dokumentasjon. 


\section{Oppsummering}

I artikkelen har jeg synliggjort to vesentlige vendepunkt i min forståelse av å undervise i skapende dans, samt hvordan min lærerrolle har utviklet seg over tid. Gjennom en fenomenologisk-narrativ tilnærming til to tekstutdrag fra et omfattende materiale har jeg tydeliggjort hva disse erfaringene har innebåret, og hvordan jeg har utvidet min pedagogrolle. Ved å sette mine personlige livsfortellinger inn i samfunnets større fortellinger, har jeg skapt meg en ny historie om meg selv, der behovet for å synliggjøre egen forforståelse også var et behov for å forstå på et eksistensielt nivå. Denne studien har også inspirert og motivert meg til å utforske forskerrollen som $\mathrm{a} / \mathrm{r} / \mathrm{tographer}$. A benytte en autoetnografisk tilnærming anser jeg som anvendelig for denne refleksjonsprosessen, der mine erfaringer og kunnskaper fra å være koreograf, dansepedagog og forskerstudent samlet kan bidra til kunnskapsutvikling om skapende dans i kroppsøvingsfaget i lærerutdanninger.

\section{English abstract}

\section{Auto-ethnographical investigation of turning points in dance education - a method for creating awareness of one's own pre-understanding in qualitative research}

This article presents an auto-ethnographical investigation of a pedagogical practice in creative dance education. This research is a part of the PhD-project "To create dance" in physical education teacher education based at The Norwegian School of Sport Sciences and The Norwegian National Graduate School in Teacher Education. The method used is based on life stories, and turning points are used as analytical tools. The turning point analysis highlights that an auto-ethnographical investigation is relevant when it comes to creating awareness of pre-understandings in the development of pedagogical experiences from one's own research field. In addition, the article shows that the turning point analysis may contribute to increasing knowledge on how one's own experience can change when narrated in new ways. Finally, the study shows that making use of auto-ethnography may also have value as a reflexive approach for becoming more conscious of one's own research process.

\section{Forfatterpresentasjon}

Trine Ørbæk er PhD-stipendiat ved Norges idrettshøgskole og Nasjonal forskerskole for lærerutdanning der hun forsker på hvordan kroppsøvingslærerstudenter utvikler profesjonskompetanse i å skape dans. Ørbæk har koreografiutdannelse fra Statens balletthøgskole (nå Kunsthøgskolen i Oslo), praktisk-pedagogisk utdannelse fra NTNU, Master of Art i Performance studies fra De Montfort University i England og ulike kurs innen økonomi, psykologi, pedagogikk, kultur- og kjønnsteori. Ørbæk har arbeidet som koreograf innenfor et bredt utvalg av scenekunstformer, undervist i dans fra barnehager til høgskolenivå og er nå ansvarlig for emnet «Dans, lek og læring» ved faglærerutdanningen i kroppsøving ved Norges idrettshøgskole.

\section{Referanser}

Annfelt, T. (2000). Poststrukturalisme og forskning om kjønn - noen perspektiver og problemer. Sosiologisk tidsskrift. 8 (1), 23-37.

Anttila, E. (2007). Mind the Body: Unearthing the Affiliation Between the Conscious Body and the Reflective Mind. I L. Rouhiainen (Red.), Ways of knowing in dance and art (s. 79-99). Helsinki: Theatre Academy.

Bresler, L. (2011). "Seeing as" versus "seeing more": Cultivating connections in arts-based research. Upublisert manuskript, utdelt i forelesning i PhD -kurset: PLU 8015 Etnografi og narrative teorier, 
9.mai. 2011. Trondheim: NTNU.

PMCid:3319004

Burton, T. (2011). Painful memories: chronic pain as a form of re-membering. Memory Studies, 4, 23. Lastet ned fra http://mss.sagepub.com/content/4/1/23

http://dx.doi.org/10.1177/1750698010382158

Day, C., Stobart, G., Sammons, P., Kington, A., Gu, Q., Smees, R., \& Mujtaba, T. (2006). Research Report RR743.Variations in Teachers' Work, Lives and Effectiveness. London: Department for educational skills.

Denzin, N. K. (1989). Interpretive biography. Qualitative research methods, (17).

Davenport, D (2006a). Expanding Thinking on Teaching Dance Composition. I Journal of Dance Education, 6(1), 4-5. http://dx.doi.org/10.1080/15290824.2006.10387305

Davenport, D (2006b). Building a Dance Composition Course: An Act of Creativity. I Journal of Dance Education, 6(1), 25-32. http://dx.doi.org/10.1080/15290824.2006.10387309

Fangen, K. (2010). Deltagende observasjon. Oslo: Fagbokforlaget.

Foucault, M. (1999). Diskursens orden. Tiltredelsesforelesning ved College de France 2. desember 1979. Oslo: Spartacus forlag.

Haines, S. E. (2006). Ethics and Aesthetics. The Artist-Educator and Choreographic Process. Journal of Dance Education, 6(1), 14-18. http://dx.doi.org/10.1080/15290824.2006.10387307

Hämäläinen, S. (2007). The meaning of bodily knowledge in a creative dance-making process. I L. Rouhiainen (red.), Ways of knowing in dance and art (s.56-78). Helsinki: Theatre Academy.

Henriksen, J. O., \& Vetlesen, A. J. (2006). Nærhet og distanse. Grunnlag, verdier og etiske teorier i arbeid med mennesker. Oslo: Gyldendal.

Hertz, J. (1997) Reflexivity of voice. London: Sage. PMCid:2127646

Hyvönen, L. (2007). The Ways of Knowing and the School Reality. I L. Rouhiainen (red.), Ways of knowing in dance and art, (s. 159-178). Helsinki: Theatre Academy.

Imsen, G. (2003). Elevens verden. Innføring i pedagogisk psykologi. Oslo: Universitetsforlaget.

Irwin, R., \& de Cosson, A. (2004). (Red.). A/r/tography: Rendering self through arts based living inquiry. Vancouver, BC: Pacific Educational.

Jenssen, R. (2008). Rudolf Labans metafysiske spekulasjoner - konsekvenser for Laban-basert undervisning i skolen. I T. Ørbæk Svee (Red.), Dans og didaktikk s. 143-163). Tapir Akademiske Forlag.

Johansson, A. (2010). Narrativ teori och metod. Med livsberättelsen i fokus. Lund: Studentlitteratur.

Katz, J., \& Csordas, T. J. (2003). Phenomenological Ethnography in Sociology and Anthropology. I Ethnography, 4, 275. http://dx.doi.org/10.1177/146613810343001

Kauppuila, H. (2007). Becoming an Active Agent in Dance and Through Dancing: A Teacher's Approach. I L. Rouhiainen (red.), Ways of knowing in dance and art (s. 133-143). Helsinki: Theatre Academy.

Laban, R. (1988). Modern Eductional Dance. Guernsey: The Guernsey Press.

Lavender, L. (2006). Creative Process Mentoring. Teaching the "Making" in Dance-Making. Journal of Dance Education, 6(1), 6 -13. http://dx.doi.org/10.1080/15290824.2006.10387306

Lilja, E., Grönlund, E., Ståhle, A. K., \& Gustafsson, G. (2006). Movement as the Memory of the Body. Stockholm: Danshögskolan.

Merleau-Ponty, M. (2012). Phenomenology of Perception. London: Routledge.

Molander, B. (1996). Kunskap i handling. Gøteborg: Daidalos.

Purcell Cone, T (2009). Following Their Lead. Supporting children's ideas for creating dances. Journal of Dance Education, 9(3), 81-89. http://dx.doi.org/10.1080/15290824.2009.10387390

Reeder, H. P. (2010). The theory and practice of Husserl's phenomenology. Bucharest: Zeta books. http://dx.doi.org/10.7761/9789731997216 
Van Manen, M. (1990). Researching Lived Experience. Human Science for an Action Sensitive Pedagogy. New York: State University Press.

Østern, A. L. (2008). Pedagogisk teori for estetiske fag - om kunstneriske læringsprosesser og om å undervise på estetisk nivå. I T. Ørbæk Svee (red.), Dans og didaktikk (s. 19-37) Trondheim: Tapir.

Østern, T. P. (2009). Meaning-making in the dance laboratory: exploring dance improvisation with differently bodied dancers (Doktorgradsavhandling). Theatre Academy. Helsinki. 